\title{
Prevalence of polypharmacy and interactions in older adults in primary care
}

\begin{abstract}
The increase of the medical prescription in the elderly population represents a problem that requires appropriate intervention. It usually entails a risk for patient morbidity and frequent hospital admissions.
\end{abstract}

Objective: To determine the prevalence of polypharmacy and its interactions in older adults in primary care in Mexicali during 2016.

Methods: Observational, longitudinal, descriptive and retrospective study, in older patients with polypharmacy attending the Family Medicine Unit (UMF) No.28 of Mexican Institute of Social Security (IMSS), through the collection and analysis of data obtained from medical records from 384 elderly patients.

Results: The mean patient age was 71.2 years; majority were female $(65.75 \%)$. The prevalence of polypharmacy in the study group was $34.83 \%$. Patients were, on average, prescribed 7.5 medications by their primary care physician. The number of drug interactions averaged 3.8 per patient. Moderate interactions (847) were the most predominant in our study, although all types of severity were found (518 mild, 72 severe). Kidneys were the main organs at risk of injury.

Conclusions: The prevalence of polypharmacy in the elderly within our environment is comparable to that in the international field.

Keywords: elderly, polypharmacy, drug interaction, primary care, adverse drug events
Volume 2 Issue 5 - 2018

\author{
Erick Mercado Ramírez,' Carlos Alberto \\ Cotenna Alcaráz, ${ }^{2}$ María Elena Haro Acosta, ${ }^{3}$ \\ Rafael Iván Ayala Figueroa, ${ }^{4}$ Joan Dautt Silva ${ }^{5}$ \\ 'Resident of Family Medicine, Family Medicine Unit No 28 of \\ Mexican Institute of Social Security (IMSS), México \\ ${ }^{2}$ Family doctor, Family Medicine Unit No 28 of Mexican Institute \\ of Social Security (IMSS), México \\ ${ }^{3}$ DC. and Pediatrician, Coordinator in Health Research, \\ Delegación Baja California of IMSS, Mexico \\ ${ }^{4}$ Coordinator in Basic Area at the Faculty of Medicine of \\ Mexicali,Autonomous University of Baja California, México \\ ${ }^{5}$ Medical Intern, Family Medicine Unit No 28 of Mexican \\ Institute of Social Security (IMSS), México
}

\begin{abstract}
Correspondence: María Elena Haro Acosta, DC. and Pediatrician, Coordinator in Health Research, Delegación Baja California of IMSS, Calzada Cuauhtémoc No.300, Colonia Aviación, C.P. 21230. Mexicali, B.C. México, Email maria.haroa@ imss.gob.mx, lenaharo@live.com.mx
\end{abstract}

Received: June 25, 2018 | Published: October 01, 2018

\section{Introduction}

The increase of drug prescription in the elderly population represents a problem that requires an appropriate intervention. Medical prescriptions are one of the most useful tools in patient care. However, problems arise when the number of drugs administered to patients is exceeded. Polypharmacy is defined as the simultaneous use of four or more drugs in a patient. ${ }^{1,2}$ Pharmacological interactions emerge as a result of two or more drugs being used at the same time. It may present itself as a pharmacological, therapeutic or toxic effect with a different (higher/lower) intensity than expected. ${ }^{3}$ The increased prevalence of chronic and degenerative diseases in older adults has led them to be the patients with most medications. In fact, around $85 \%$ of patients aged $>60$ years taking, either doctor or self prescribed medicine, may end up presenting non-optimal or null pharmacological effects. For these reasons, polypharmacy has been considered as a geriatric syndrome. ${ }^{4,5}$ There are tools that list potentially inappropriate medications that should be avoided in this type of patients, such as the BEERS or the STOPP-STAR criteria. ${ }^{6}$ We could not find articles that categorize interactions according to severity or organ injury risk. Internationally, polypharmacy and inadequate prescription in hospitalized patients aged 65 years or more, varies from 5.8 to $51.4 \%$. In Mexico, the prevalence of polypharmacy in the elderly has been reported from 25.8 to $35 \%$ in different studies. It has become more frequent in recent years, which increases the risk of morbidity in such patients. Therefore, the objective of this study is to determine the prevalence of polypharmacy and its drug interactions in elderly patients ascribed to the UMF No. 28 in Mexicali in 2016.

\section{Material and methods}

Observational, longitudinal, descriptive and retrospective study carried out in the UMF No.28 of the IMSS in Mexicali, during the year 2016. We calculated a sample size with the finite population formula ( $95 \%$ confidence level, $p=0.50$ (maximum indeterminate), permissible error level 0.05 ) out of the population aged $>60$ years ascribed there (39,372 patients). The result was 385 patients. We reviewed each patient's file and collected the following data: age, sex, number and name of prescribed medications. In order to know the pharmacological interactions, the IDoctus electronic tool was used. The drugs supplied to each patient were entered to determine the type and number of interactions. The interactions presented were later classified according to the program in one of four categories: without interaction, mild interactions, moderate interactions and serious interactions. All of this information was later inputted in a Microsoft Excel worksheet.

\section{Statistical analysis}

Descriptive statistics were used for the analysis of the variables, using measures of central tendency and dispersion for quantitative variables and percentages for qualitative variables. These variables were stored in a data file and analyzed using the SPSS v.21 program.

\section{Results}

The universe of elderly patients assigned to the UMF No. 28 was 39,372 in 2016, of which 385 patients were our sample size. According to sex, 252 were women $(65.5 \%)$ and 133 were men $(34.5 \%)$. The mean patient age was 71.2 years. The prevalence of polypharmacy in elderly patients was $34.8 \%$ in our study group. Per patient, the number of prescribed drugs and pharmacological interactions averaged 7.5 and 3.8 respectively Table 1 . In our cohort, we found a total of 1,458 drug interactions: 518 were mild, 847 moderate and 72 serious. The most prevalent interactions, according to severity, from mild to serious, were: Metoprolol-Metformin $(\mathrm{n}=68,13.1 \%)$, Bezafibrate- 
Pravastatin $(\mathrm{n}=54,6.4 \%)$ and Fluoxetine-Metoprolol $(\mathrm{n}=15,20.8 \%)$. Other common interactions found can be seen in Figure 1, Figures 2 and Figures 3 in relation to severity. Regarding potential organ risk, 269 interactions were associated with kidney damage. Other systems at jeopardy of damage were the cardiovascular (104), musculoskeletal (55) and gastrointestinal (37) systems Figure 4. Table 2 summarizes the effects of some of the more common interactions found. Only 50 $(12.9 \%)$ patients did not present any type of drug interaction.

Table I General characteristics of the population

\begin{tabular}{lll}
\hline Variable & Frequency (\%) & Media \pm DE \\
\hline Gender & $252(64.45)$ & \\
Women & $133(34.55)$ & \\
Mens & & \\
Age (years) & & \\
Average medication & & \\
Prescribed & & \\
Average drug interactions per & 3.8 & \\
patient & & \\
$\begin{array}{l}\text { Patients who presented drug } \\
\text { interactions }\end{array}$ & $335(87)$ & \\
\hline
\end{tabular}

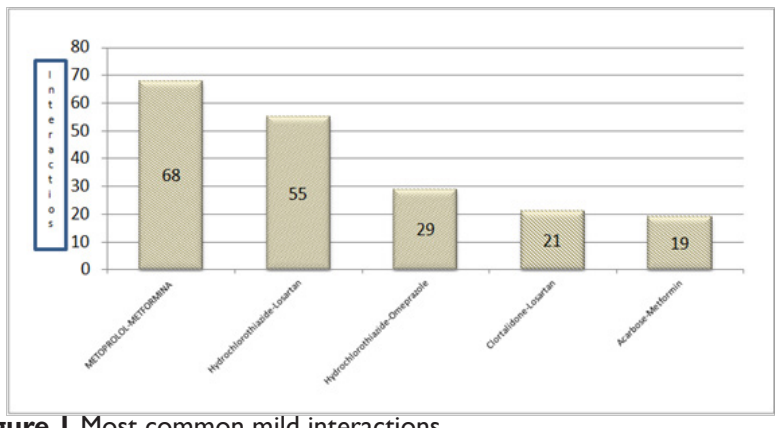

Figure I Most common mild interactions. $n=518$

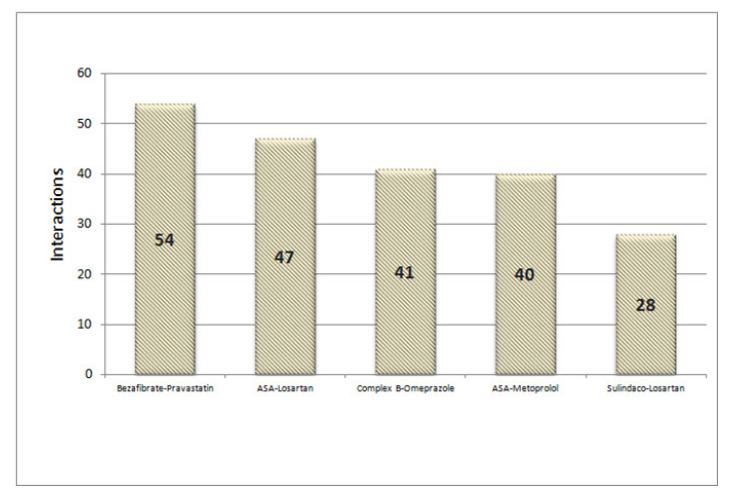

Figure 2 Most common moderate interactions. $n=847$

Table 2 Combination of drugs and pharmacological interaction

\begin{tabular}{|c|c|c|}
\hline Interaction & Combination & Pharmacological interaction \\
\hline \multirow[t]{7}{*}{ Serious } & Fluoxetine-Metoprolol & High risk of complete heart block \\
\hline & Clopidogrel-Omeprazole & $\begin{array}{l}\text { Possible decrease in antiplatelet activity and lack of efficacy of Clopidogrel, with the consequent increase in } \\
\text { the risk of atherothrombotic events (reinfarctions or recurrence of an acute coronary syndrome) }\end{array}$ \\
\hline & Enalapril-Losartan & $\begin{array}{l}\text { Possible increase in the risk of hyperkalemia, hypotension and renal failure, without additional benefits in } \\
\text { terms of global mortality }\end{array}$ \\
\hline & Indomethacin-Losartan & $\begin{array}{l}\text { Possible decrease in antihypertensive effect with risk of loss of antihypertensive control of the patient. The } \\
\text { combination of an ACE inhibitor or ARA or an NSAID may increase the risk of hyperkalemia and renal } \\
\text { failure. }\end{array}$ \\
\hline & $\begin{array}{l}\text { Glibenclamide- } \\
\text { Acetylsalicylic acid (ASA) }\end{array}$ & The hypoglycemic action of sulfonylureas is enhanced with simultaneous administration of ASA. \\
\hline & Digoxin-Spironolactone & $\begin{array}{l}\text { Possible increase in plasma levels of cardiotonic. } \\
\text { Digoxin poisoning hazard. }\end{array}$ \\
\hline & Fluoxetine-Risperidone & $\begin{array}{l}\text { The joint administration of risperidone with SSRI can lead to an organic accumulation of risperidone, which } \\
\text { can lead to toxic effects. }\end{array}$ \\
\hline \multirow[t]{5}{*}{ Moderate } & Combination & Pharmacological interaction \\
\hline & Bezafibrate-Pravastatin & The joint use, risk of accumulation of statins with toxic effects such as rhabdomyolysis. \\
\hline & ASA-Losartan & $\begin{array}{l}\text { Possible decrease in antihypertensive effect with risk of loss of antihypertensive control of the patient. } \\
\text { Accumulation of an ACE inhibitor or ARA and an NSAID may increase the risk of hyperkalemia and renal } \\
\text { failure. }\end{array}$ \\
\hline & Complex B-Omeprazole & Possible reduction of vitamin absorption \\
\hline & ASA-Metoprolol & $\begin{array}{l}\text { The administration of ASA in higher doses, together with metoprolol or other beta-blockers can produce a } \\
\text { reduction of the hypotensive effect of the latter agents. }\end{array}$ \\
\hline
\end{tabular}


Table continued...

\begin{tabular}{|c|c|c|}
\hline Interaction & Combination & Pharmacological interaction \\
\hline \multirow{7}{*}{ Mild } & Sulindaco-Losartan & $\begin{array}{l}\text { Possible decrease in antihypertensive effect with risk of loss of antihypertensive control of the patient. } \\
\text { Accumulation of an ACE inhibitor or ARA and an NSAID may increase the risk of hyperkalemia and renal } \\
\text { failure. }\end{array}$ \\
\hline & Combination & Pharmacological interaction \\
\hline & Metoprolol-Metformin & Risk of beta-blockers masking hypoglycemia data (tachycardia and tremor). \\
\hline & $\begin{array}{l}\text { Hydrochlorothiazide- } \\
\text { Losartan }\end{array}$ & Validity association, risk of hypotension in first doses. \\
\hline & $\begin{array}{l}\text { Hydrochlorothiazide- } \\
\text { Omeprazole }\end{array}$ & Possible increased Fluoxetine-Risperidone risk of hypomagnesemia, especially in prolonged treatments. \\
\hline & Clortalidone-Losartan & Validity association, risk of hypotension in first doses. \\
\hline & Acarbose-Metformin & Acarbose with another hypoglycemic agent, risk of hypoglycaemia. \\
\hline
\end{tabular}

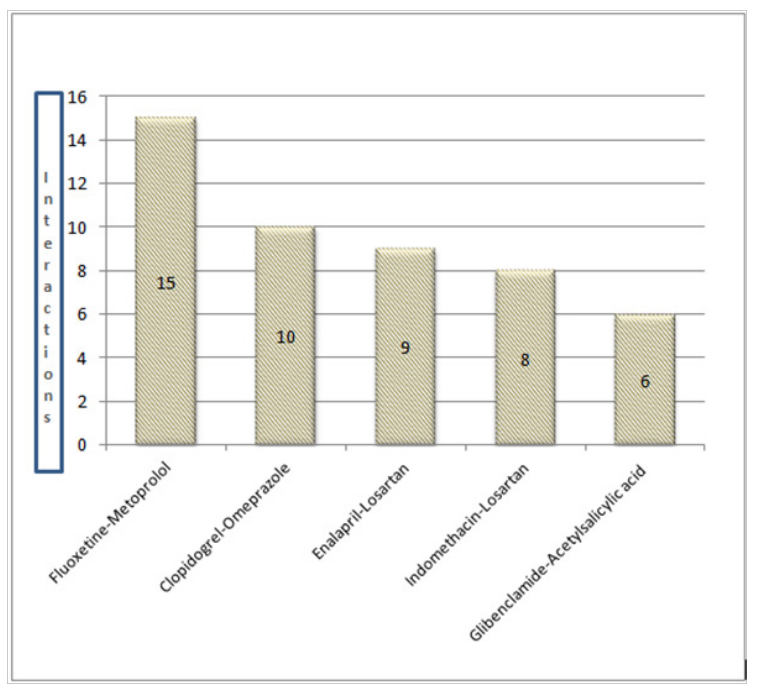

Figure 3 Most common serious drug interactions.

$\mathrm{n}=72$



Figure 4 Organs and systems that are at risk of being affected by Polypharmacy.

\section{Discussion}

The prevalence of polypharmacy within the population of older adults ascribed to the UMF No.28 (34.8\%) is lower than what was previously reported in Spain (46\%) and other Mexican studies (50\% in Monterrey, $36 \%$ in Sonora). ${ }^{3-8}$ Meanwhile, the average of prescribed medications (7.5) is higher than the average in a Barcelona study (6.4) and in Hermosillo (5.4). However, it was lower than in Obregón (8.1). ${ }^{4}$ ${ }^{9}$ Regarding the average of interactions per patient (3.8 \pm 1.8 ), there is no bibliography with which this result can be compared. Trying to compare the prevalence of patients without drug interactions, despite having polypharmacy, yielded the same results. Currently, no previous studies have classified drug interactions according to severity; they do, however, report the most frequent interactions found in their study population and its adverse effects. Among them is a study conducted in Spain that reported 6 main interactions: Omeprazole-Acenocoumarol, Metformin-Hydrochlorothiazide, Furosemide-Digoxin, ClopidogrelAtorvastatin, Furosemide-Salbutamol and Atenolol-Mephtormin, ${ }^{10}$ none of which was found in our study. Other studies focus on drug frequently prescribed ${ }^{5-13}$ or those associated with adverse effects or certain side effects, like Acenocoumarol (which was not present in our study), ${ }^{14}$ while others calculated only main side effects and measured their effect on health related quality of life..$^{15}$ There were 1,468 drug interactions, of which 269 were associated with risk of kidney damage, similar to a prior study that showed drug related side effects. ${ }^{15}$ As stated before, no studies categorized drug interactions based on organ damage.

\section{Conclusion}

This study shows that inappropriate medical prescription represents a risk to public health by, either compromising the performance of some treatments, or creating a greater morbidity to already sick patients. The prevalence of polypharmacy in the elderly in our environment is lower than previous international and national studies. Nevertheless, it is necessary to make strategies to prevent it. Continuous training constitutes one of the key interventions that need to be reinforced in order to guarantee adequate prescription use and reduce the risks associated with unjustified polypharmacy.

\section{Acknowledgments}

To the pharmacy department for their collaboration in providing the database.

\section{Conflict of interest}

The authors declare there is no conflict of interest. 


\section{References}

1. Informe Mundial sobre el Envejecimiento y la Salud.

2. María Luisa Peralta-Pedrero, Francisco Javier Valdivia-Ibarra, Mario Hernández-Manzano, Guía de la Práctica Clínica para la prescripción farmacológica razona para el adulto mayor. México: Secretaria de Salud. 2010;51(2):228-239.

3. Gac H. Polifarmacia y morbilidad en adultos mayores. Rev Med Clin Condes. 2012;23(1):31-35.

4. García LM, Villareal E, García L, et al. Costo de la polifarmacia en pacientes con diabetes mellitus tipo 2. Rev Med Chile. 2015;143:606-611.

5. Jasso JC, Tovar A, Cuadros J. Prevalencia de prescripción de medicamentos potencialmente inapropiados a la población geriátrica de un hospital privado de la Ciudad de México. Med Int Mex. 2011;27(6):527-534.

6. Davies EA, O’Mahony MS. Adverse drug reactions in special populationsthe elderly. Br J Clin Pharmacol. 2015;80 (4):796-807.

7. Martínez-Arroyo JL, Gómez-García A, Sauceda-Martínez, D. Prevalencia de la polifarmacia y la prescripción de medicamentos inapropiados en el adulto mayor hospitalizado por enfermedades cardiovasculares. Gac Med Mex. 2014;150 (Suppl 1):29-38.

8. Canale-Segovia A, Álvarez-Hernández G, Cuen-Rendón RE, CandiaPlata MC. Prevalencia de polifarmacia en adultos mayores residentes de estancias de Hermosillo, Sonora. Unison Epistemus. 2014;17(8):32-40.
9. Castañeda-Sánchez O, Valenzuela-García B. Análisis de costos de la polifarmacia en ancianos. Aten Fam. 2015;22(3):72-76.

10. Velasco-Sánchez M, Juárez-Molera E, López-Parra E, et al. Análisis de las interacciones medicamentosas en la población extrahospitalaria mayor de 65 años. Semergen. 2011;37(5):233-237.

11. Serra-Urra M, Germán-Meliz JL. Polifarmacia en el adulto mayor. Rev Haban Cienc Med. 2013;12(1):142-151.

12. Gavilán-Moral E, Morales-Suárez-Varela MT, Hoyos-Esteban JA, et al. Polimedicación y prescripción de fármacos inadecuados en pacientes ancianos inmovilizados que viven en la comunidad. Aten Primaria. 2006;38(9):476-482.

13. Paci JF, García-Alfaro M, Redondo-Alonso FJ, et al. Prescripción Inadecuada en pacientes polimedicados mayores de 64 años en atención primaria. Aten Primaria. 2015; 7(1):38-47.

14. Velázquez-Portillo MGL, Gómez-Guerrero R. Frecuencia y factores asociados al empleo de polifarmacia en pacientes hospitalizados en el servicio de urgencias. Arch Med Urg Mex. 2011;3(2):49-54.

15. Sánchez-Gutiérrez R, Flores-García A, Aguilar-García P, et al. Efectos de la polifarmacia sobre la calidad de vida en adultos mayores. Rev Fuente. 2012;4(10):70-75. 